\title{
Figur Intelektual Muslim dalam Al-Qur'an: Tafsir Tematik Terhadap Kata Ulul Albab
}

\author{
Ahmad Dibul Amda \\ Institut Agama Islam Negeri (IAIN) Curup \\ dibulamda2019@gmail.com
}

DOI: $10.29240 /$ alquds.v4i1.1450

Submitted: 2019-03-30 | Revised: 2020-04-13 |Accepted: 2020-04-28

\begin{abstract}
The main issues addressed in this study are the meaning and nature of the word Ulul Albab in the Qur'an. In general, some theories say that Ulul Albab means a person who has intelligent thoughts, conscious heart, who is opened and understand the essence beyond the physical nature. The word also refers to one who enjoys what he sees and knows, and who always remembers Allah The Almighty through all things he sees and touches. Those meaningsare similar to the meaning of the term "Intellectual" in the general senseknown bynowadays people. So, can the term Ulul Albab be translated into "Intellectual Muslim"?, and how is then the Qur'anic conception of Ulul Albab's existences and characteristics?Thus, this study deals with the meanings and essence of Ulul Albab in the Qur'an, the characteristics of Ulul Albab, and how to build Ulul Albab characteristics properly? This is a library research. The data analysis used content analysis on the material object in the form of verses of the Qur'an by using Thematic Interpretation Method approach (التفـسـيـرالمـوضـوعى) (al-Tafsir alMaudbu'i) as a formal object, and supported by some relevant theories. The objective of this research is to find out the valid and concrete data or theories about the meanings and nature of Ulul Albab in the Qur'an. This research results in several conclusions that; the term Ulul Albab in the Qur'an has the same meaning as the term "Intellectual Muslim", Al-Qur'an describes several characteristics of Ulul Albab and how to build and developed the mentioned characteristics.
\end{abstract}

Keywords: Ulul Albab, Characteristicts, Intelectual Muslim, Thematic Exegesis

Abstrak. Figur Intelektual adalah seorang yang mempunyai kecerdasan yang tinggi,
banyak ilmu dan bewawasan luas. Adapun Ulul Albab di dalam al-Qur'an adalah orang
yang memiliki pikiran yang cerdas, qalbu yang senantiasa sadar, terbuka, dan
memahami hakikat yang ada dibalik lahiriah. Juga yang memanfaatkan apa yang dilihat
dan diketahuinya, yang ingat kepada Allah Swt melalui segala sesuatu yang dilihatnya
dan disentuhnya. Apakah Ulul Albab tersebut sama denga Figu intelektual? Penelitian
ini betujuan untuk mendeskripsikan makna Ulul Albab di dalam al-Qur'an dengan istilah
Intelektual Muslim, karakteristik dan cara-cara membina karakteistik Ulul Albab
menurut al-Qur'an. Penelitian ini menggunakan metode deskriptif Qualitatif dengan 
pendekatan Tafsir Tematik. Fokus penelitian ini adalah ayat-ayat al-Qur'an, yang mengandung kata Ulul Albab. Teknik analisis, menggunakan Konten Analisis. Hasil penelitian menunjukkan kata Ulul Albab mempunyai arti yang sama dengan istilah Intelektual Muslim tetapi Ulul Albab juga bearti Orang yang beriman dan hatinya selalu bezikir kepada Allah. Al-Qur'an sekaligus menjelaskan tentang cara-cara membina karakteristik Ulul Albab.

Kata Kunci: Ulul Albab, Karakteristik, Intelektual Muslim, Tafsir al-Maudhu’i

\section{Pendahuluan}

Istilah Ulul Albab yang dikemukakan Al-Qur'an sebanyak enam belas kali dalam sepuluh surat dan dalam konteks yang berbeda-beda. Berdasarkan ayat tersebut dapat diambil suatu pengertian bahwa : Ulul Albab adalah seorang yang mampu memetik pelajaran (hikmah) terhadap fenomena yang ada di sekelilingnya baik itu gejala-gejala alam maupun perilaku sosial. ${ }^{1}$ Konsep intelektual dalam Islam digali dalam perluasan makna kalimat ini. Kata Ulul Albab disebutkan dalam Al-Qur'an dalam beberapa ayat, dan didahului dengan perintah untuk melihat ciptaan Allah dan segala kuasa-Nya. Lalu diperintahkan juga untuk menggunakan daya pikir berkaitan dengan hal tersebut atau dengan kata lain melakukan kegiatan intelektual. Maka konsep intelektual Islam sebenarnya juga berpikir, tetapi harus dibarengi dengan dzikir. Dengan kata lain, Ada dua sisi yang disorot oleh Islam yaitu sisi rasional (dengan akal/pikiran) dan sisi intuitif (dengan dzikir, mengingat Allah, dan dengan wahyu/petunjuk dari Allah). ${ }^{2}$

Mereka inilah yang menggunakan daya berpikir, akal, budi dan kecerdasannya dalam lingkupan dunia Islam. Dengan kata lain, kita bisa menyebutnya dengan "kaum cendekiawan muslim". Banyak diantara mereka yang merupakan para ulama/ahli agama, ahli sosial, ahli kemasyarakatan, ahli ekonomi bahkan ahli tekhnologi dan komunikasi yang berkecimpung di dunia Islam. Oleh mereka inilah keintelektualan Islam masih terus berkembang hingga sekarang. Adapun dalam mengetahui perkembangan keintelektual Islam, kita perlu mengetahui terlebih dahulu sejarah munculnya tradisi intelektual muslim itu sendiri. ${ }^{3}$

Secara historis intelektual Islam bermula dari turunnya wahyu kepada Nabi Muhammad SAW. Surah Al-Alaq ayat 1-5 menggambarkan perintah Allah

${ }^{1}$ M. Quraish Shihab, Tafsir Al-Mishbah: Pesan, Kesan Dan Keserasian al-Qur'an, vol. 2 (Jakarta: Lentera Hati, 2011), h. 382.

${ }^{2}$ Abdul Munir Mulkhan, Paradigma Intelektual Muslim, Pengantar Filsafat Pendidikan Islam Dan Dakwah (Yogyakarta: Pustaka Pelajar, 2003), 43.

${ }^{3}$ Ibid., 51. 
SWT kepada seluruh umat Islam untuk ber'intelektual' ${ }^{4}$. Kata-kata bacalah, pelajaran, dan pena merupakan aktifitas keintelektualan. Dalam sejarah intelektual Islam, betapa ilmu pengetahuan sangat diagungkan. ${ }^{5}$ Bahkan AlQur'an dan sunnah banyak menggunakan peribaratan (perumpamaan/ permisalan) tentang fadbilah atau keutamaan orang yang menuntut ilmu. Kata ilmu dalam Al-Qur'an diulang sebanyak 780 kali. Konsep longlife education (belajar dari buaian sampai sepanjang hayat) sudah dikenal pada masa kelahiran Islam. Implikasinya mendorong terciptanya masyarakat ilmu (knowledge society) dan budaya ilmu (knowledge culture). Para pemimpin Islam sesudah Nabi ikut andil besar dalam perkembangan pengetahuan masyarakat Islam. Mereka menyiarkan semangat keilmuan ke berbagai negara yang dilampaui oleh Islam. ${ }^{6}$

Diantara tanda-tanda intelektual Islam yang berkembang semarak pada zaman itu diantaranya adalah berdirinya madrasah hadits dan fiqh di Madinah. Lalu diikuti oleh madrasah-madrasah lainnya yang tumbuh menjamur di pusatpusat kota Islam di zaman setelahnya. Demikian berkembangnya intelektual Islam semakin pesat sesudah futub al-buldan (pembebasan negara-negara). Percampuran budaya antar umat Islam dengan negara-negara yang ditakhlukkan merupakan faktor timbulnya inisiatif untuk mengadopsi ilmu-ilmu para ilmuwan asing untuk diterjemahkan ke dalam bahasa Arab yang merupakan bahasa persatuan umat Islam. Kebanyakan buku-buku tersebut adalah buku-buku Yunani termasuk diantaranya karangan Plato dan Aristoteles. Buku-buku tersebut mencakup bidang kedokteran, matematika, astronomi, fisika, filsafat, astrologi dan kimia. Lalu muncullah para ilmuwan Muslim disertai dengan lahirnya beragam aliran-aliran pemikiran, ataupun mazhab dimasing-masing bidang keilmuan, seperti filsafat, ushul fiqh, tasawuf dan sebagainya. Semua itu membuat intelektual Islam semakin menggeliat. ${ }^{7}$

Diketahui bahwa agama Islam sangat tidak menganjurkan orang-orang yang enggan berpikir dan hanya ber-taqlidul a'ma bighairi hudan. Hanya bisa mengikuti membabi buta dan mengiyakan perkataan yang belum diketahui kebenarannya. Baik dari segi kehidupan spritual terhadap Tuhan dan segala hal yang berhubungan dengan umat manusia. Umat Muslim sangat dianjurkan untuk menangkap ilmu, memahami dan mengerti akan banyak hal secara konseptual. Orang-orang seperti inilah yang diharapkan oleh Umat dan sesuai dengan konsep 'Ulul Albab' didalam Al-Qur'an. Yang akan menjadikan keintelektualan 2002), 57

${ }^{4}$ Imam Bawani, Cendekiawan Muslim Dalam Perspektif Islam (Surabaya: PT. Bina Ilmu,

5 Ibid., 64.

${ }^{6}$ Mulkhan, Paradigma Intelektual Muslim, 59.

${ }^{7}$ Ali Syari'ati, Tugas Cendekiawan Muslim (Jakarta: Rajawali Press, 1991), 58. 
Islam kembali bergeliat dan bersemarak. Juga yang akan menjadikannya menjalar ke seluruh lapisan masyarakat. ${ }^{8}$

Al-Quran yang merupakan firman Allah yang diturunkan kepada Nabi Muhammad menyimpan segudang ilmu pengetahuan serta lengkap dengan solusi perihal kehidupan duniawi. Ayat pertama yang diturunkan kepada Nabi Muhammad adalah iqra'. Wahyu pertama ini menjelaskan dan menghendaki umatnya untuk membaca apa saja selama bacaan tersebut Bismi Rabbik, dalam arti bermanfaat untuk kemanusiaan. Iqra' yang berarti bacalah, telitilah, dalamilah, ketahuilah ciri-ciri sesuatu; bacalah alam, tanda-tanda zaman, sejarah maupun diri sendiri, baik yang tertulis maupun yang tidak. ${ }^{9}$

Dengan demikian jelas bahwa al-Qur'an (Allah) sangat menjunjung tinggi aspek ilmu pengetahuan dan intelektualitas. Kenapa intelektualitas? Karena pengembangan aspek intelektualitas bisa menjadikan umat lebih maju, berperadaban dan tauhidi. Ini telah terbukti dalam sejarah kehidupan umat Islam, dimana dengan intelektualitasnya, umat Islam mampu merubah peradaban manusia dari kebobrokan moral dan kegelapan intelektual menuju kepada peradaban tinggi yang sesuai dengan petunjuk Sang Ilahi. Dengan memaksimalkan fungsi akal, sehingga dunia Islam telah berhasil menciptakan para ilmuawan, kaum intelektual dan cendekiawan, sehingga menjadikan Islam sebagai center peradaban dunia.

Dalam Al-Qur'an, banyak terdapat ayat-ayat yang bisa menjadi inspirasi dan motivasi berpikir, banyak ayat-ayat yang menekankan agar manusia mau menggunakan akalnya untuk memikirkan kebesaran dan ke-Esaan Tuhannya yang termanivestasi di alam semesta ini. Seperti ayat-ayat yang mengandung seruan, tidakkah kalian memikirkan?, tidakkah kalian berfikir? tidakkah kalian perhatikan? Tidakkah mereka memerhatikan? Ungkapan itu semua merupakan sebuah perintah penggunaan akal yang bisa dijadikan sebagai motivasi awal untuk menjadi seorang intelektual. ${ }^{10}$

Dari penomena dan problematika di atas, timbul sejumlah permasalahan ilmiah, antara lain Apakah Kata Ulil Al-Babab di dalam Al-Qur'an dapat diartikan dengan para Intelektual?, Bagamaina Konsepsi Al-Qur'an tentang Karakteristik Figur Intelektual?. Bagaimana membina karakteristik dan Intelektualitas dalam konsepsi Al-Qu"an? Sejumlah permasalahan akademik tersebut perlu dibahas secara lebih integral dan mendalam karena menyangkut dengan pemahaman ajaran agama dan ilmu pengetahuan. Dan itu semua sudah tentu di dalam Al-Qur'an akan ditemui jawabannya secara jelas dan rinci.

306.

${ }^{8}$ Bawani, Cendekiawan Muslim Dalam Perspektif Islam, 73.

${ }^{9}$ Manna al-Qaththân, Mababits Fi 'Ulum al-Qur'An (Kairo: Maktabah Wahbah, 2000),

${ }^{10}$ Harun Nasution, Akal Dan Wahyu Dalam Islam (Jakarta: UI Press, 1996), 36. 


\section{"Ulul Albab" dan Temanya dalam Quran}

Term Ulul Albab (أُولُؤ الََْلَبَبِ) di dalam teks ayat-ayat alqur'an sebanyak 16 kali di beberapa tempat dan topik yang berbeda, yaitu dalam QS. al-Baqarah: 179,197, 269; QS. Ali Imran: 7, 190; QS. al-Maidah: 100; QS. Yusuf: 111; QS.al Ra'd: 19; QS. Ibrahim: 52; QS. Shad: 29,43; QS. al-Zumar: 9, 18, 21; QS. alMu'min: 54 dan QS. al Thalaq: $10 .{ }^{11}$ Hal ini secara detail dapat dipahami dari "Tabel 1" berikut ini:

Tabel 1. Terma Ulul Albab dalam Quran

\begin{tabular}{cll}
\hline No. & \multicolumn{1}{c}{ Quran/Surat } & \multicolumn{1}{c}{ Tema } \\
\hline 1. & Al-Baqarah: 179 & Tema Qisas \\
2. & Al-Baqarah: 197 & Haji dan Aturan Syariatnya \\
3. & Al-Baqarah: 269 & Hikmah Paham Quran \\
4. & Ali Imran: 7 & Isi Pokok Quran \\
5. & Ali Imran: 190 & Penciptaan Langit dan Bumi \\
6. & Al-Maidah: 100 & Ketakwaan \\
7. & Yusuf: 111 & Hikmah Kisah dalam Quran \\
8. & Al-Rad: 19 & Kebenaran Quran \\
9. & Ibrahim: 52 & Penjelasan Sempurna Quran \\
10. & Shaad: 29 & Keberkahan Quran \\
11. & Az-Zumar: 9 & Keberuntungan Ahli Ibadah \\
12. & Al-Mu'min: 54 & Quran sebagai Petunjuk \\
\hline
\end{tabular}

Tentu ada banyak term ulul albab yang muncul dalam surat dan ayat Quran. Hanya saja jika diperhatikan, pola kemunculan dan penggunaan terma ini dalam Quran selalu dalam konteks yang konsisten seperti: a) ajakan untuk memikirkan kekuasan Allah ta'ala; b) keberuntungan orang yang menggunakan akal pikiran; c) kebenaran Quran; dan d) kemahakuasaan Allah ta'ala dalam menciptakan alam semesta. Tak berlebihan jika dalam melakukan interperasi makna 'ulul albab' ini para mufasir berbeda pendapat. Kendati tidak sedikit pula yang memiliki kesamaan dalam pemaknaan. Karena itu, agaknya penting mendeskripsikan bagaimana terma ulul albab ditafsirkan dan dihubungkan dengan konsep "figur intelektual muslim.”

${ }^{11}$ Lihat Ali Audah, Konkordansi Qur'an: Panduan Kata Dalam Mencari Ayat Qur'an, Cet. 1 (Bogor: Pustaka Litera AntarNusa, 1991), 601-2 dan 626-27.; Dan lihat juga Muhammad Said al-Liham, Al-Mu'jam al-Mufahras Li Alfařb al-Qur'an (Beirut: Dar al-Ma'rifah, 2002), 860-63.; Dan lihat juga Muhammad Fu'ad Abd al-Baqi, Al-Mu'jam al-Mufahras Li Alfąh al-Qur'an al-Karim (Beirut: Dar Al-Fikr, 1417), 644.. 


\section{Ulul Albab dan Relasinya dengan Konsep Figur Intelektual Muslim}

Para mufassir menafsirkan terma Ulul Albab dengan penafsiran yang berbeda-beda. Hal ini disebabkan Ulul Albab adalah istilah khusus yang dipakai Al-Quran untuk menyebutkan sekelompok manusia pilihan semacam intelektual. Istilah itu disebutkan sebanyak 16 kali dalam Al-Quran. Namun sejauh itu AlQuran sendiri tidak menjelaskan secara definitive konsepnya tentang Ulul Albab. Ia hanya menyebutkan tanda-tandanya saja. Al-Maragi, dalam Tafsirnya, menjelaskan bahwa Ulul Albab adalah orang-orang yang mempunyai akal dan pemahaman. $^{12}$ Demikian dijelaskan beliau ketika menafsirkan firman Allah Swt dalam surat Al-Baqarah ayat 179. Lafazh Ulul Albab pada ayat tersebut adalah: orang-orang yang mempunyai akal yang bersih dari noda-noda keraguan. ${ }^{13}$

Menurut Ibnu Katsir, Ulul Albab adalah orang-orang yang punya akal cerdas dan mau berpikir tantang hal-hal yang berguna (berilian). ${ }^{14}$ Menurut AlMaraghi, "Ulul Albab yaitu orang-orang yang berakal lurus dan benar". Lebih lanjut beliau menjelaskan orang yang berakal disebut secara khusus pada surat Al-Ma'idah ayat 100, yaitu orang-orang yang mengerti serta memahami akibat berbagai perkara setelah memikirkan hakikeat dan sifatnya." "Allah menganugerabkan Al bikmah (kefahaman yang dalam tentang Al Quran dan As Sunnab) kepada siapa yang dikehendaki-Nya. dan barangsiapa yang dianugerabi bikmah, ia benar-benar Telah dianugerabi karunia yang banyak. dan Hanya orang-orang yang berakallah yang dapat mengambil pelajaran (dari firman Allah) (Qs. Al-Baqarah: 269). Menurut Hasbi AsShiddiqy, Hikmat adalah akal yang merdeka, yang sanggup mempelajari sesuatu beserta dalil-dalilnya dan mampu memahami semua urusan(masalah) menurut hakikatnya. Ibnu Abbas menafsirkan hikemat dalam ayat ini dengan "mengetahui Fiqh Al-Quran", yaitu mengetahui petunjuk hukum beserta rahasia-rahasia yang terkandung didalamnya dan hikmatnya. Orang yang memahami ayat-ayat infak, manfaat dan tata caranya, tentulah hatinya tidak bisa dipengaruhi oleh bisikan setan. $^{16}$

Menurut Jalaluddin Al-Mahalli dan Jalaluddin As-Suyuti mengartikan Ulul Albab sebagai "orang yang berakal sehat". ${ }^{17}$ Kemudian Quraisy Shihab ketika menafsirkan Al-Qur'an Surat Ar-Ra'du ayat 19 mengartikan Ulul Albab

${ }^{12}$ Ahmad Ibn al-Musthafâ al-Maraghi, Tafsir Al-Maraghi (Mesir: al-Bâb al-Halabî, 1946), j. 1,53 .

13 TM. Hasbi Ash-Shiddieqy, Tafsir Al-Bayan (Bandung: Al-Ma'arif, 1971), 341.

${ }^{14}$ Imaduddin Abi al-Fida Isma’il ibn Katsir, Tafsir Al-Qur'an al-Az̧him (Kairo: Maktabah al-Shafa, 2004), j. 1, 421.

15 al-Maraghi, Tafsir Al-Maraghi, j. 8, 223.

16Ash-Shiddieqy, Tafsir Al-Bayan, 475.

${ }^{17}$ Jalâl al-Dîn Muhammad Ibn Ahmad al-Mahalli and Jalâl al-Dîn 'Abdurrahman Ibn Abi Bakr al-Suyûthî, Tafsir Jalalain (Kairo: Dar al-Hadits, n.d.), 980. 
bukan sekadar yang memiliki kemampuan berfikir cemerlang, tetapi kemampuan berfikir yang disertai dengan kesucian hati sehingga dapat mengantar pemiliknya meraih kebenaran dan mengamalkannya serta menghindar dari kesalahan dan kemungkaran. Itulah saripati manusia. Adapun jasmaninya, tidak lain adalah kulit yang menutupi sari pati itu. Namun demikian tentu saja kulit juga harus dipelihara agar sari pati itu tidak terganggu. ${ }^{18}$

Sedangkan menurut Sayyid Qutb ketika menafsirkan 16 ayat-ayat ulul Albab beliau mengemukakan Ulul Albab dengan beberapa makna yang berbedabeda sesuai dengan konteks ayat yang ada yaitu: Dalam Qs. Al-Baqarah ayat 179 (Sayyid Qutb JI : 173), Qs. Ibrahim ayat 52 (Sayyid Qutb JIV : 114), Qs. AlMaidah ayat 100 (Sayyid Qutb JII : 335), Qs. Yusuf ayat 111 (Sayyid Qutb JIV : 23), Ulul Albab diartikan dengan "orang-orang yang berakal." Dalam Al-Qur'an Surat Al-Baqarah ayat 197 Ulul Albab di artikan "orang yang berakal" yaitu orang-orang yang pertama kali mendapatkan pengarahan kepada taqwa, dan sebaik-baik orang yang mempergunakan bekal ini. ${ }^{19}$ Dalam Al-Qur'an Surat. AlBaqarah ayat 269 Ulul Albab adalah "Orang yang berakal sehat" yaitu orang yang selalu ingat dan tidak lupa, orang yang selalu sadar dan tidak lengah, dan orang yang dapat mengambil pelajaran sehingga tidak masuk kedalam kesesatan. Inilah tugas akal. Fungsinya adalah mengingat arahan-arahan hidayah dan petunjukpetunjuknya, sehingga tidak hidup dengan lengah dan lalai. ${ }^{20}$

Dalam Al-Qur'an Surat Ali Imran ayat 7 Ulul Albab adalah orang yang lebih jujur fitrahnya karena fitrahnya itu senantiasa berhubungan dengan maha benar dan merasa mantap dan tenang kepada-Nya. ${ }^{21}$ Dalam Al-Qur'an Surat Al-Imran ayat 190 Munasabab dengan ayat 191 ulul Albab adalah orang-orang yang memiliki pemikiran, dan pemahaman yang benar. ${ }^{22}$ Sedang ketika Munasabah dengan ayat 194 Ulul Albab adalah orang yang mempunyai hati yang sehat sejahtera dan terbuka yang sangat sensitif, sangat cermat, halus, takwa, dan malunya mereka kepada Allah Swt. ${ }^{23}$ Al-Qur'an Surat Ar-Ra'du ayat 19 Ulul Albab adalah orang yang memiliki akal dan hati yang sehat, mengingat kebenaran lantas mengambil pelajaran, dan menyadari petunjuk-petunjuk lantas merenungkannya. ${ }^{24}$

${ }^{18}$ M. Quraish Shihab, Tafsir Al-Misbab: Pesan, Kesan Dan Keserasian Al-Qur'an Jakarta: Lentera Hati, 2002), j. 6, 258.

${ }^{19}$ Sayyid Quthb, Fi Zhilal Al-Qur'an (Kairo: Dar al-Syuruq, 1998), 234.

${ }^{20}$ Ibid., 312.

${ }^{21}$ Ibid., 367.

22 Ibid., 544.

${ }^{23}$ Ibid., 248.

${ }^{24}$ Ibid., j. 4, 2056. 
Dalam Al-Qur'an Surat Az-Zumar ayat 9 Ulul Albab adalah para pemilik qalbu yang senantiasa sadar, terbuka, dan memahami hakikat yang ada dibalik lahiriah. Juga yang memanfaatkan apa yang dilihat dan diketahuinya, yang ingat kepada Allah Swt melalui segala sesuatu yang dilihatnya dan disentuhnya. ${ }^{25}$ Sedangkan dalam Al-Qur'an Surat Az-Zumar ayat 18 Ulul Albab adalah "akal yang sehat" ialah yang menuntut pemiliknya kepada kesucian dan keselamatan, barang siapa yang tidak mengikuti jalan kesucian dan keselamatan, maka seolaholah akalnya telah direnggut dan tidak akan merasakan nikmat akal yang telah dianugerahkan kepadanya. ${ }^{26}$ Dan Al-Qur'an Surat Az-Zumar ayat 21 Ulul Albab adalah orang yang melakukan perenungan serta yang memanfaatkan akal dan pemahaman yang di karuniakan Allah Swt kepadanya. ${ }^{27}$ Dalam Al-Qur'an Surat Al-Mu'min ayat 54 Ulul Albab diartikan dengan "orang-orang yang berpikir". ${ }^{28}$ Dalam Al-Qur'an Surat At-Thalaq ayat 10 Ulul Albab adalah orang-orang yang beriman yang telah dituntun oleh hati mereka kepada keimanan dalam menghadapi peringatan dan fenomena-fenomena yang panjang. ${ }^{29}$ Sedangkan dalam Al-Qur'an Surat Shaad ayat 29 dan 43 Ulul Albab diartikan dengan "orang-orang yang berakal dan mempunyai pikiran". ${ }^{30}$

Jadi pengertian Ulul Albab adalah orang yang memiliki sesuatu yang murni (fitrah), berakal sehat, akal yang bersih dari cela, memiliki pemahaman yang cemerlang dari akal dan qalbu, memiliki kebijaksanaan, dapat membaca fenomena alam dan fenomena masyarakat, ingat kepada Allah Swt mampu menjaga ketaqwaan kepada-Nya sehingga tetap mengingat arahan-arahan hidayah dan petunjuk-petunjuk-Nya. Konsep intelektual Islam sebenarnya juga berpikir, tetapi harus dibarengi dengan dzikir. Dengan kata lain, Ada dua sisi yang disorot oleh Islam yaitu sisi rasional (dengan akal/pikiran) dan sisi intuitif (dengan dzikir, mengingat Allah, dan dengan wahyu/petunjuk dari Allah). ${ }^{31}$ Mereka inilah yang menggunakan daya berpikir, akal, budi dan kecerdasannya dalam lingkupan dunia Islam. Dengan kata lain, kita bisa menyebutnya dengan "kaum cendekiawan muslim". Banyak diantara mereka yang merupakan para ulama/ahli agama, ahli sosial, ahli kemasyarakatan, ahli ekonomi bahkan ahli tekhnologi dan komunikasi yang berkecimpung di dunia Islam. Oleh mereka inilah keintelektualan Islam masih terus berkembang hingga sekarang. Adapun dalam mengetahui perkembangan keintelektual Islam, kita perlu mengetahui terlebih dahulu sejarah munculnya tradisi intelektual muslim itu sendiri. ${ }^{32}$

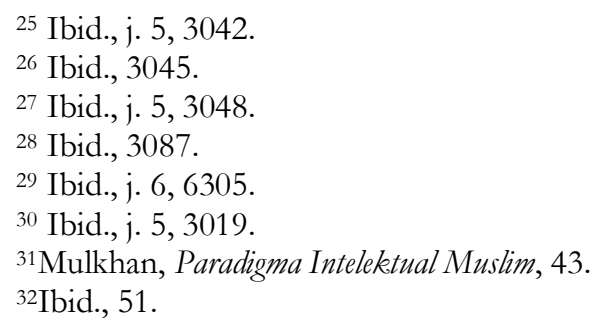


Secara historis intelektual Islam bermula dari turunnya wahyu kepada Nabi Muhammad SAW ${ }^{33}$. Surah Al-Alaq ayat 1-5 menggambarkan perintah Allah SW'T kepada seluruh umat Islam untuk ber'intelektual'. Kata-kata bacalah, pelajaran, dan pena merupakan aktifitas keintelektualan. Dalam sejarah intelektual Islam, betapa ilmu pengetahuan sangat diagungkan. ${ }^{34}$ Umat Muslim sangat dianjurkan untuk menangkap ilmu, memahami dan mengerti akan banyak hal secara konseptual. Orang-orang seperti inilah yang diharapkan oleh Umat dan sesuai dengan konsep 'Ulul Albab' didalam Al-Qur'an. Yang akan menjadikan keintelektualan Islam kembali bergeliat dan bersemarak. Juga yang akan menjadikannya menjalar ke seluruh lapisan masyarakat. ${ }^{35}$ Dari penafsiranpenafsiran dan pendapat-pendapat di atas, dapat disimpulkan bahwa terma Ulul Albab dapat diterjemahkan dengan istilah "Para Intelektual Muslim."

\section{Ulul Albab: Identifikasi Karakter dan Tipologinya dalam Quran}

Dalam Konkordansi Quran ${ }^{36}$, ada 16 ayat yang menggunakan kata Ulul Albab. Namun tidak ada satu pun ayat yang secara lugas memberi definisi tentang Ulul Albab. Tapi, dari apa yang disampaikan Al-Quran bisa diidentifikasi karakteristik yang melekat pada figur Ulul Albab. Dalam penjelasan tafsir Fi Zhilaali Al-Quran, Ulul Albab itu tidak hanya yang berpikir tentang alam fisik, botani, dan sejarah ${ }^{37}$. Merekapun ternyata mempunyai karakteristik yang berkaitan tidak hanya dengan aktivitas pikirnya, melainkan juga dengan amal konkritnya ${ }^{38}$. Dalam Al-Qur'an, surat Ar-Raad, ayat 19-22, Secara garis besar dijelaskan bahwa Ulul Albab adalah orang yang memiliki karakteristik sebagai berikut: Pertama, Orang Yang Mempunyai Pengetahuan atau Orang Yang Tahu. Dalam QS. Ar- Raad : 19 :

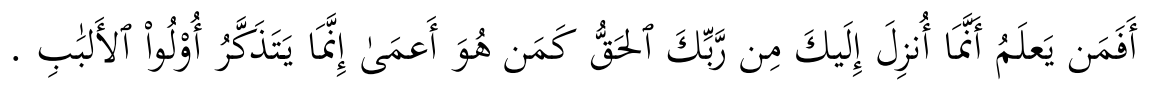

"Adakah orang yang mengetahui bahwasanya apa yang diturunkan kepadamu dari Tubanmu itu benar sama dengan orang yang buta? hanyalah orang-orang yang berakal saja yang dapat mengambil pelajaran"

${ }^{33}$ Bawani, Cendekiawan Muslim Dalam Perspektif Islam, 57.

${ }^{34}$ Ibid., 64.

${ }^{35}$ Ibid., 73.Bawani, Op. Cit., hlm. 73

${ }^{36}$ Lihat Audah, Konkordansi Qur'an, 601-2 dan 626-27.; Lihat juga al-Liham, Al-Mu'jam al-Mufabras Li Alfarh al-Qur'an, 860-63.; Lihat juga Abd al-Baqi, Al-Mu'jam al-Mufahras Li Alfažb al-Qur'an, 644.

${ }^{37}$ Quthb, Fi Zhilal Al-Qur'an, 426.

38 Ibid., 427. 
Menurut Sayyid Qutb, ${ }^{39}$ Lawan atau kebalikan dari orang yang mengetahui bahwa apa yang diturunkan (wahyu) dari Tuhanmu itu benar bukanlah orang yang tidak mengetahui hal ini. Tetapi, lawan atau kebalikannya ialah orang yang buta. Namun kebutaannya ini adalah kebutaan mata hati, tumpulnya penalaran, tertutupnya kalbu, redupnya sinar makrifah di dalam ruh, dan terpisahnya dari sumber cahaya, sehingga "banyalah orang-orang yang berakal saja yang dapat mengambil pelajaran". Kesungguhan mencari ilmu dan kecintaannya mensyukuri nikmat Allah. Seperti disebutkan dalam Al-Quran:

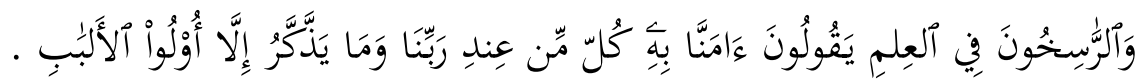

"Dan orang yang "bersunggubsungguh dalam ilmu pengetabuan mengembangkannya dengan seluruh tenaganya, sambil berkata: Kami percaya, ini semuanya berasal dari hadirat Tuban kami,' dan tidak mendapat peringatan seperti itu kecuali Ulul Albab. "..dan orang-orang yang mendalam ilmunya berkata: "Kami beriman kepada ayat-ayat yang mutasyaabihaat, semuanya itu dari sisi Tuhan kami." dan tidak dapat mengambil pelajaran (daripadanya) melainkan orang-orang yang berakal". (QS. Ali Imran:7)

Kesenangan mereka mentafakkeuri ciptaan Allah di langit dan di bumi juga termasuk dalam bersungguh-sungguh mencari ilmu. Allah menyebutkan tanda Ulul Albab ini sebagai berikut: "Sesungguhnya dalam proses penciptaan langit dan bumi, dalam pergiliran siang dan malam, adalah tanda-tanda bagi Ulul Albab." Dalam Qs. Ali Imrn: 190 ; "Sesunggubnya dalam penciptaan langit dan bumi, dan silib bergantinya malam dan siang terdapat tanda-tanda bagi orang-orang yang berakal" Jadi dalam karakter pada ayat di atas adalah mereka orang yang memiliki akal dan hati yang mengerti, mengingat kebenaran lantas mengambil pelajaran, dan menyadari petunjuk-petunjuknya lantas merenungkannya. ${ }^{40}$ Kedua, Orang Yang Memenuhi Perjanjian Dengan Allah Swt dan Tidak Akan Ingkar Dari Janji Tersebut (yaitu beriman, berbuat baik dan menjauhi yang keji dan mungkar). Sebagaimana firman Allah Swt dalam Quran surah ar-Raad: 20 disebutkan:

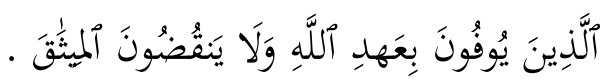

"(Yaitu) orang-orang yang memenubi janji Allah dan tidak merusak perjanjian".

Janji Allah Swt disini mutlak, meliputi semua macam perjanjian; janji terbesar yang menjadi pokok pangkal semua perjanjian ialah janji iman. Pakta terbesar yang menjadi tempat bertumpunya semua pakta (perjanjian) ialah perjanjian untuk setia menunaikan segala konsekuensi iman ini. Dari perjanjian ketuhanan ini dilanjutkanlah dengan perjanjian kepada sesama musia, baik terhadap rasul maupun terhadap orang lain, baik yang masih ada hubungan

39 Ibid.

${ }^{40}$ Ibid., 47. 
kekerabatan maupun tidak, perseorangan maupun kolektif. Maka, orang yang memelihara perjanjian yang pertama sudah tentu akan memelihara perjanjianperjanjian lainnya, karena memelihara itu merupakan suatu kewajiban. ${ }^{41}$

Dari ayat diatas, Jalaluddin Rakhmat mengutip pendapat Muhammad Hijazi pada at-tafsir al-wadhih menyebutkan perjanjian ini disebut mitsaq. Ia mendefinisikannya sebagai "Apa yang mengikat diri mereka dalam hubungan antara mereka dengan Tuhannya, antara mereka dengan diri mereka sendiri, dan antara mereka dengan manusia yang lain". Seorang intelektual harus memilih commitmennya, kaitannya pada nilai-nilai seorang intelektual muslim ialah ia memilih untuk commitmen dengan nilai-nilai Islam. Memenuhi mitsaq berarti tetap setia pada commitment yang dipilih. ${ }^{42}$ Ketiga, yang Menyambung Apa yang diperintahkan oleh Allah Swt untuk disambung, (misalnya ikatan cinta kasih). Dalam Quran surah ar-Raad 21 :

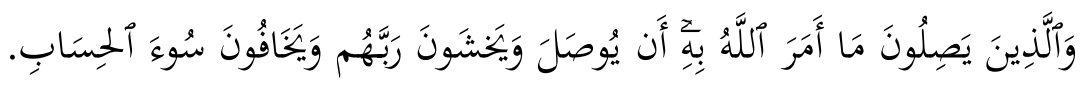

"Dan orang-orang yang mengbubungkan apa-apa yang Allab perintabkan supaya dibubungkan, dan mereka takut kepada Tubannya dan takut kepada bisab yang buruk"

Menyambungkan apa yang diperintahkan Allah Swt, meliputi segala hal, dan bukan hanya silaturrahmi. Termasuk didalamnya "menggabungkan iman dan amal cinta kepada Allah Swt dengan cinta kepada manusia". Demikianlah sifat-sifat mereka secara garis besar. Apa saja yang diperintahkan Allah Swt supaya disambung, mereka sambung, yaitu ketaatan yang paripurna, istiqamah yang berkesinambungan, dan berjalan di atas sunnah sesuai dengan aturan-Nya dengan tidak menyimpang dan tidak berpaling. Yang dimaksud ialah sikap yang mutlak yang tidak berbelok-belok, ketaatan mutlak yang tidak berpaling, dan hubungan mutlak yang tidak putus-putus. ${ }^{43}$ Keempat, takut kepada Tuhan (jika berbuat dosa) karena takut kepada hasil perhitungan yang buruk.

Karakteristik Ulul Albab yang ini, seperti yang tertulis pada surat ArRaad: 21 di atas. Gaya bahasa ayat ini menyinarkan ketaatan yang sempurna itu kedalam perasaan dan hati yang bersangkutan sebagaimana dilukiskan, "Dan mereka takut kepada Tuhannya dan takut kepada hisab yang buruk". Yaitu takut kepada Allah dan takut kepada siksaan yang buruk dan menyedihkan pada hari pertemun yang menakutkan. Mereka itulah Ulul Albab yang memikirkan hisab (perhitungan) sebelum datangnya yaumul bisab. ${ }^{44}$ Merasa takut hanya kepada

\footnotetext{
41 Ibid.

42 Jalaluddin Rahmat, Islam Alternatif (Bandung: Mizan, 1999), 201.

43Ibid., 48.

${ }^{44}$ Ibid.
} 
Allah (QS. Al-Baqarah: 197 dan al-Thalaq: 10). Dalam Quran surah al-Baqarah 197 :

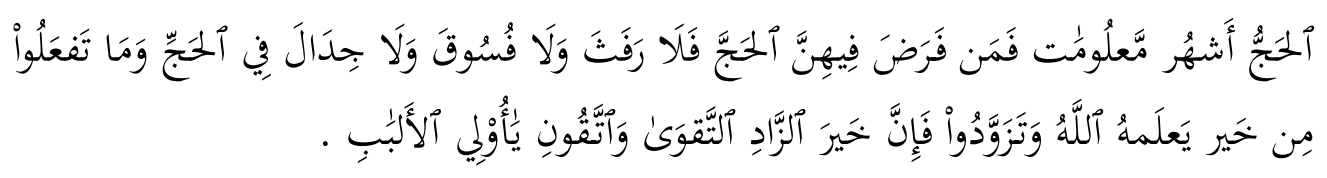

"Musim haji adalab beberapa bulan yang dimaklumi, barangsiapa yang menetapkan niatnya dalam bulan itu akan mengerjakan haji, Maka tidak boleh rafats, berbuat fasik dan berbantah-bantahan di dalam masa mengerjakan haji. dan apa yang kamu kerjakan berupa kebaikan, niscaya Allah mengetahuinya. Berbekallah, dan Sesunggubny a sebaik-baik bekal adalah takwa dan bertakwalah kepada-Ku Hai orang-orang yang berakal”.

Ibnu Katsir menjelaskan ayat di atas bahwa: Takutlah terhadap hukuman, siksaan dan azab-Ku, yaitu bagi orang yang menyalahi, tidak melaksanakan perintah-Ku, wahai orang-orang yang mempunyai pemikiran dan pemahaman. ${ }^{45}$ Hasbi As-Shidieqy menguraikan ayat diatas yaitu "berikhlaslah kepada-Ku wahai orang yang berakal, dengan menunaikan segala rupa fardhu yang aku wajibkan dan menjauhi segala yang Aku haramkan, supaya kamu terlepas dari apa yang kamu takuti yaitu siksa neraka dan azab-Ku. Supaya kamu memperoleh apa yang kamu cari, yaitu keridhaan-Ku dan rahmat-Ku." ${ }^{46}$ Orangorang yang berakal dan mau berfikir (Ulul Albab) diperintahkan untuk berikhlas kepada Allah Swt melakukan kewajiban-kewajiban dan menjauhi apa yang diharamkan kepada mereka, dengan demikian mereka akan selamat dari kemurkaan dan siksaan Allah Swt yang pedih. Mereka akan selamat memperoleh apa-apa yang dicita-citakan selama ini, yaitu: kebahagiaan mendapat keridhaan dan rahmat Allah Swt. Allah Swt juga berfirman:dalam surah at-Thalaq 10-11:

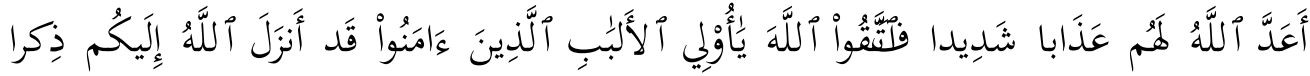

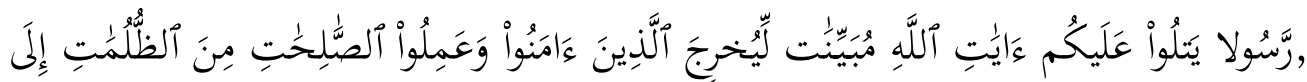

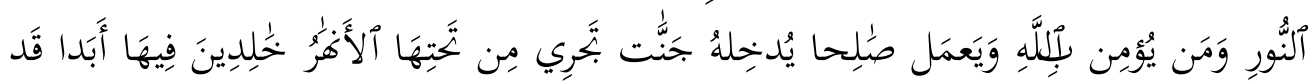

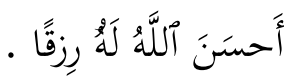

"Allah menyediakan bagi mereka azab yang keras, Maka bertakwalah kepada Allah Hai orangorang yang mempunyai akal; (yaitu) orang-orang yang beriman. Sesunggubnya Allah Telah menurunkan peringatan kepadamu, (dan mengutus) seorang Rasul yang membacakan kepadamu ayat-ayat Allah yang menerangkan (bermacam-macam bukum) supaya dia mengeluarkan orang-orang yang beriman dan beramal saleh dari kegelapan kepada cahaya.

45 ibn Katsir, Tafsir Al-Qur'an al-Az̧bim, j. 1, 278.

46 TM. Hasbi Ash-Shiddieqy, Tafsir Al-Qur'an al-Majid An-Nur (Semarang: Pustaka Rizki Putra, 1995), 328. 
dan barangsiapa beriman kepada Allah dan mengerjakan amal yang saleb niscaya Allah akan memasukkannya ke dalam surga-surga yang mengalir di bawahnya sungai-sungai; mereka kekal di dalamnya selama-lamanya. Sesunggubnya Allab memberikan reqki yang baik kepadanya."

Menurut Al-Maraghi ${ }^{47}$, Redaksi ini ditujukan kepada Ulul Albab dimaksudkan untuk menjelaskan kepada mereka nilai tuntutan dan petunjuk yang diturunkan kepada mereka. Hal ini terwujud dalam diri Rasulullah Saw yang menjadi bentuk perwujudan keimanan yang hidup dalam sunnah dan sirahnya, dan ia mengeluarkan mereka dari kegelapan menuju cahaya” Dalam ayat ini Allah Swt menerangkan juga bahwa orang yang senantiasa memperhatikan keingkaran dan pembangkangan mereka untuk mengikuti ajaran-ajaran para rasul yang berasal dari Allah Swt. Bagi mereka itu telah disediakan azab yang keras di kemudian hari, oleh karena itu orang-orang yang berakal dan beriman harus bertakwa kepada-Nya, karena Allah Swt telah menurunkan peringatan yaitu Al-Quran yang memperingatkan segala sesuatunya untuk menjadi pegangan dengan mengamalkan serta mematuhi isinya. Kelima, yang Sabar Karena Ingin Mendapat Ridha Allah Swt. Karakter Ulul Albab yang selanjutnya ada di dalam firman Allah Swt surah ar-Raad : 22) :

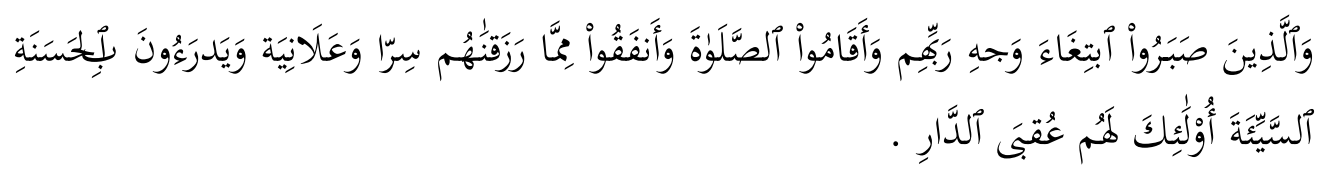

"Dan orang-orang yang sabar Karena mencari keridhaan Tubannya, mendirikan shalat, dan menafkabkan sebagian rezki yang kami berikan kepada mereka, secara sembunyi atau terang-terangan serta menolak kejahatan dengan kebaikan; orang-orang Itulah yang mendapat tempat kesudahan (yang baik)"

Ada bermacam-macam bentuk sabar dan sabar memiliki konsekuensi konsekuensi, Yaitu sabar atas semua beban perjanjian-perjanjian di atas (seperti beramal, berjihad, berdakwah, berijtihad dan sebagainya), sabar dalam menghadapi kenikmatan dan kesusahan serta kesulitan (karena sedikit sekali orang yang dapat bersabar didalam menghadapi kenikmatan sehingga tidak sombong dan tidak kufur), dan sabar dalam menghadapi kebodohan dan kejahilan manusia yang sering menyesakkan hati. ${ }^{48}$ Mereka bersabar atas nikmat dan cobaan-Nya, serta bersabar dengan menerima qadha dan qadar-Nya, menyerah kepada kehendak-Nya, dan menerima segalanya dengan senang hati. Dan semuanya dilakukannya semata hanya untuk mencari ridha Allah Swt. ${ }^{49}$

\footnotetext{
47 al-Maraghi, Tafsir Al-Maraghi, j. 27, 243.

${ }^{48}$ Quthb, Fi Zhilal Al-Qur'an, 48.

${ }^{49}$ Ibid.
} 
Keenam, menegakkan Shalat. Mendirikan shalat ini juga termasuk memenuhi perjanjian dengan Allah Swt. Dan sekaligus lambang penghadapan diri secara tulus dan sempurna kepada Allah Swt. Juga merupakan hubungan yang jelas antara hamba dengan Tuhan, yang tulus dan suci. Sehingga tidak ada satupun gerakan dan ucapan selain Allah Swt. ${ }^{50}$ Ketujuh, membelanjakan Rizki yang Diperoleh Untuk Kemanfaatan Orang Lain, Membelanjakan rizki di sini ialah menginfakkan hartanya dengan baik seperti zakat, shadaqah, dan lain-lain baik secara terang-terangan maupun sembunyi-sembunyi. Infak (zakat) ini juga untuk membersihkan jiwa orang yang berzakat dari penyakit bakhil, dan membersihkan hati orang yang menerimanya dari penyakit hasad atau iri hati. Dan infak ini juga menjadikan kehidupan masyarakat muslim sebagai masyarakat yang suka tolong menolong dan memiliki kepedulian sosial yang mulia atas dasar mencari keridhaan Allah Swt. ${ }^{51}$

Kedelapan, menolak Kejahatan dengan Kebaikan. Menolak kejahatan dengan kebaikan adalah membalas kejahatan dengan kebaikan dalam pergaulan sehari-hari, bukan dalam urusan agama. Karena membalas kejelekan dengan kebaikan itu akan melemahkan keburukan jiwa yang bersangkutan, mengarahkanya kepada kebaikan, memadamkan api permusuhan, dan dapat menolak gangguan setan. Dengan demikian, kejelekan dan keburukan itu akan tertolak. Tetapi, kalau dibalas dengan kebaikan justru akan menambah keberaniannya berbuat jahat, maka tidak ada tempat untuk membalasnya dengan kebaikan, agar kejahatan dan keburukan tidak semakin merajalela dan semakin menjadi-jadi. Karena pengarahan Qur'aniah dilakukan dengan mempertimbangkan situasi dan kondisi, dengan dimusyawarahkan oleh para Ulul Albab, lantas diambil tindakan yang lebih baik dan lebih cepat. Mereka dengan kedudukan yang tinggi itu mendapat tempat kesudahan yang baik, yaitu surga 'adn sebagai tempat tinggal dan tempat menetap, sebagaimana firman Allah:

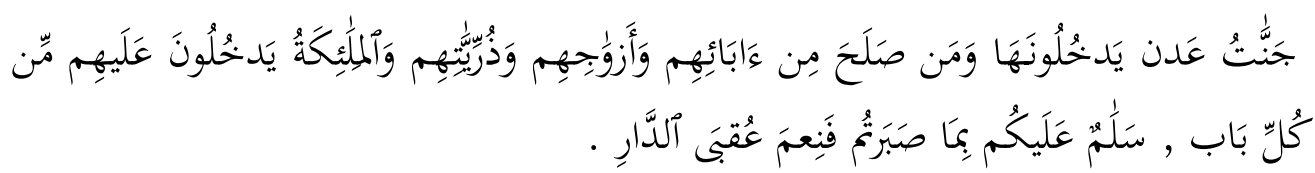

"(yaitu) syurga 'Adn yang mereka masuk ke dalamnya bersama-sama dengan orang-orang yang saleh dari bapak-bapaknya, isteri-isterinya dan anak cucunya, sedang malaikatmalaikat masuk ke tempat-tempat mereka dari semua pintu; (sambil mengucapkan): "Salamun 'alaikum bima shabartum (artinya: keselamatan atasmu berkat kesabaranmu)". Maka alangkah baiknya tempat kesudahan itu." (Qs. Ar-Raad: 23-24.)

Keadaan mereka layaknya sebuah festival atau reuni dimana mereka saling bertemu, mengucapkan salam, dan melakukan perbuatan-perbuatan yang

\footnotetext{
50 Ibid.
}

51 Ibid. 
menyenangkan dan menggembirakan serta penuh dengan penghormatan. ${ }^{52}$ Sedangkan dipihak lain adalah orang-orang yang tidak memiliki akal pikiran yang sehat dan tidak mau mengingat Allah Swt serta tidak memiliki mata hati untuk memandang. Maka, keadaan mereka bertentangan dengan Ulul Albab.

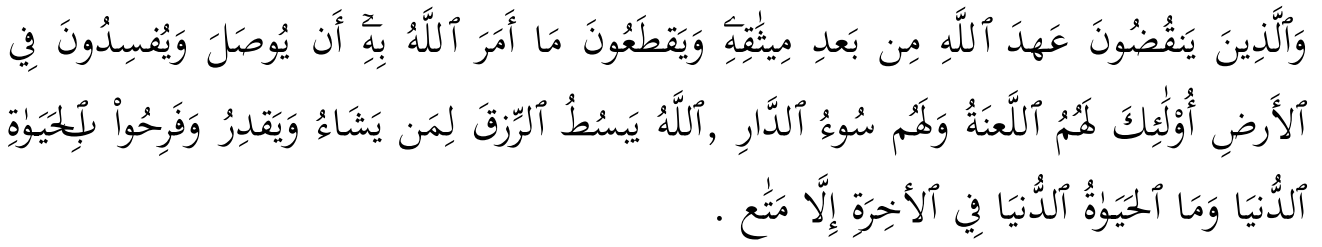

"Orangorang yang merusak janji Allah Swt setelah diikerarkan dengan teguh dan memutuskan apa-apa yang Allab Swt perintabkan supaya dibubungkan dan mengadakan kerusakan di bumi, orang-orang Itulah yang memperoleh kutukan dan bagi mereka tempat kediaman yang buruk (Jahannam). Allah Swt meluaskan rizki dan menyempitkannya bagi siapa yang dia kehendaki. mereka bergembira dengan kebidupan di dunia, padahal kehidupan dunia itu (dibanding dengan) kehidupan akhirat, hanyalab kesenangan (yang sedikit)."(Qs. Ar-Raad: 25-26).

Kesembilan, bersikap kritis dalam menerima pengetahuan atau mendengar pembicaraan orang lain. Ulul albab memiliki kemampuan menimbang ucapan, teori, proposisi dan atau dalil yang dikemukakan orang lain (QS. Al-Zumar: 18):

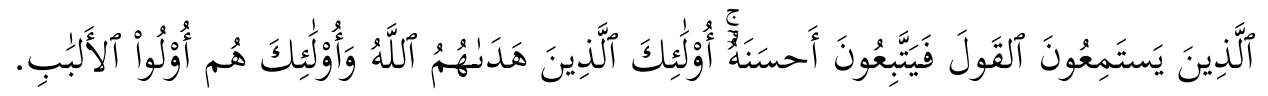

"Yang mendengarkan perkataan lalu mengikuti apa yang paling baik di antaranya. mereka Itulah orang-orang yang Telah diberi Allab Swt petunjuk dan mereka Itulah orang-orang yang mempunyai akal."

Ulul Albab, mendengar perkataan yang telah mereka dengar. Lalu qalbu mereka memungut bagian tuturan yang baik dan membuang sisanya. Sesungguhnya Allah Swt mengetahui kebaikan yang ada pada jiwa mereka. Maka, Dia menunjukkan mereka untuk menyimak dan merespon perkataan yang baik. Petunjuk itu adalah petunjuk Allah Swt. ${ }^{53}$ Allah Swt memberikan sifat kepada mereka tiga hal: bertauhid kepada Allah Swt atau menjauhi thaghut, kembali kepada Allah Swt, dan mengikuti perkataan yang paling benar (wahyu). ${ }^{54}$ Yaitu bahwa perkataan-perkataan yang mereka dengarkan, mereka memperhatikan baik-baik, pasang telinga menyalakan mata dan sambut dengan penuh kesadaran, lalu mengikuti mana yang tebaik.

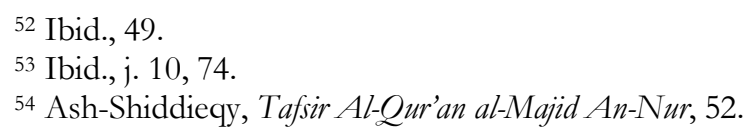


Hamka mengutip satu tafsir dari Ibnu Abbas: "didengarkannya ada katakata yang baik dan ada yang tidak baik untuk didengar. Maka yang dipegangnya ialah yang baik, sedang yang tidak baik didengar itu tidak dipercakapkannya." ${ }^{55}$ Hasbi As-Shidieqy mengutip ayat di atas dengan menguraikan; Ya Muhammad, gembirakanlah hamba-hamba-Ku yang menjauhi diri dari penyembah selain Allah Swt dan kembali kepada Tuhan, serta mau mendengarkan perkataan yang benar, lalu mengikuti mana yang lebih utama untuk diterima dan mana yang dapat menunjuk kepada kebenaran, bahwa mereka akan diberikan oleh Allah Swt nikmat yang kekal di dalam surga (jannatun na'im). Merekalah orang-orang yang ditaufiqkan oleh Allah Swt kepada kebenaran, bukan orang-orang yang berpaling dari kebenaran dan menyembah berhala. Orang itulah yang mempunyai akal yang sejahtera dan fitrah yang sehat yang tidak dapat ditundukkan oleh hawa nafsu. Karena itu senantiasa mereka memilih mana yang lebih baik untuk agama dan dunianya. ${ }^{56}$ Allah Swt memuji mereka bahwa mereka adalah orang-orang yang kritis dalam beragama, mereka dapat membedakan antara yang baik dan yang lebih baik, dan antara utama dengan yang lebih utama. Orang-orang yang mendengarkan perkataan yang baik dan mengerjakan yang baik dari perkataan itu adalah orang yang mendapat taufiq dari Allah Swt dan selalu menggunakan akal pikirannya. ${ }^{5}$

Hamka mengutip dari tafsir Al-Kasyaaf yaitu Zamakhsyari menguraikan tafsir ayat ini: maksud ayat ini adalah mendidik mereka agar mereka dalam hal agama hendaklah kritis, dapat memilih diantara yang baik dengan yang lebih baik. Yang utama dengan yang sangat utama, termasuk didalamnya dalam memilih suatu pendirian mazhab, diantara dua yang bagus mana yang lebih kokoh, mana yang lebih kuat ketika diuji, mana yang lebih jelas dalil dan alasannya, dan sekali-sekali jangan jadi orang yang hanya taqlid (menurut saja dengan tidak memakai pertimbangan akal sendiri). ${ }^{58}$ Ulul albab itulah yang termasuk golongan ahli fikir dan akal yang sempurna yaitu mereka yang dapat memahami pembicaraan orang yang merupakan petunjuk dari Allah Swt dan Rasul-Nya. Dengan demikian, dapat dinyatakan bahwa karakteristik dan ciriciri Ulul Albab adalah memiliki kualitas berupa kekuatan dzikir, fikir dan amal shaleh. Atau dalam bahasa lain, masyarakat yang mempunyai status Ulul Albab adalah mereka yang memenuhi indikator berikut; (1) Memiliki ketajaman analisis; (2) Memliki kepekaan spiritual; (4) Optimisme dalam menghadapi hidup; (5) Memiliki keseimbangan jasmani-ruhani; individual-sosial dan keseimbangan dunia-akhirat; (6) Memiliki kemanfaatan bagi kemanusiaan; (7) Pioneer dan

\footnotetext{
${ }^{55}$ Hamka, Tafsir Al-Az̧har (Jakarta: Gema Insani Press, 2015), j. 24, 62.

56 Ash-Shiddieqy, Tafsir Al-Bayan, j. 4, 548-549.

57 al-Maraghi, Tafsir Al-Maraghi, j. 23, 287.

${ }^{58}$ Hamka, Tafsir Al-Ažar, j. 8, 61.
} 
pelopor dalam transformasi sosial; (8) Memiliki kemandirian dan tanggung jawab; dan (9) Berkepribadian kokoh. ${ }^{59}$

\section{Kesimpulan}

Ulul Albab adalah para intelektual beriman yang mampu menyatukan kekuatan drikir dan fikir (mengingat dan penalaran), di samping punya kebijakan (bikmah) dalam menghadapi dan menyelesaikan masalah-masalah kemanusiaan. Karakteristik Figur Ulul Albab adalah sebagai berikut: a) Mempunyai Pengetahuan atau Orang Yang Tahu; b) Memenuhi Perjanjian Dengan Allah Swt dan Tidak Akan Ingkar dari Janji tersebut (yaitu beriman, berbuat baik dan menjauhi yang keji dan mungkar); c) Menyambung Apa Yang Diperintahkan Oleh Allah Swt Untuk disambung, (misalnya ikatan cinta kasih); d) Takut kepada Tuhan (jika berbuat dosa) karena takut kepada hasil perhitungan yang buruk; e) Sabar Karena Ingin Mendapat Ridha Allah Swt; f) Menegakkan Shalat; g) Membelanjakan Rizki yang Diperoleh Untuk Kemanfaatan Orang Lain; h) Menolak Kejahatan dengan Kebaikan; i) Bersikap kritis dalam menerima pengetahuan atau mendengar pembicaraan orang lain.

Adapun membina Karakter Figur Ulul Albab adalah dengan beberapa cara, antara lain sebagai berikut : Pertama, Menerapkan metode belajar yang melibatkan partisipasi aktif murid, yaitu metode yang dapat meningkatkan motivasi murid karena seluruh dimensi manusia terlibat secara aktif dengan diberikan materi pelajaran yang konkrit, bermakna, serta relevan dalam konteks kehidupannya (student active learning, contextual learning, inquiry based learning, integrated learning); Kedua, Menciptakan lingkungan belajar yang kondusif (conducive learning community) sehingga anak dapat belajar dengan efektif di dalam suasana yang memberikan rasa aman, penghargaan, tanpa ancaman, dan memberikan semangat; Ketiga, Memberikan pendidikan karakter secara eksplisit, sistematis, dan berkesinambungan dengan melibatkan aspek knowing the good, loving the good, and acting the good; Keempat, metode pengajaran yang memperhatikan keunikan masing-masing anak, yaitu menerapkan kurikulum yang melibatkan juga sembilan aspek kecerdasan manusia. Seluruh pendekatan di atas menerapkan prinsip-prinsip Developmentally Appropriate Practices strategy pengembangan karakter dilakukan dengan menanamkan nilai-nilai etika dasar (core ethical values) sebagai basis bagi karakter yang baik. []

\footnotetext{
${ }^{59}$ Mulkhan, Paradigma Intelektual Muslim, 22.
} 
162 | AL QUDS : Jurnal Studi Alquran dan Hadis vol. 4, no 1, 2020

\section{Bibliografi:}

Abd al-Baqi, Muhammad Fu'ad. Al-Mu'jam al-Mufahras Li Alfað̧ al-Qur'an alKarim. Beirut: Dar Al-Fikr, 1417.

Ash-Shiddieqy, TM. Hasbi. Tafsir Al-Bayan. Bandung: Al-Ma'arif, 1971.

—. Tafsir Al-Qur'an al-Majid An-Nur. Semarang: Pustaka Rizki Putra, 1995.

Audah, Ali. Konkordansi Qur'an: Panduan Kata Dalam Mencari Ayat Qur'an. Cet. 1. Bogor: Pustaka Litera AntarNusa, 1991.

Bawani, Imam. Cendekiawan Muslim Dalam Perspektif Islam. Surabaya: PT. Bina Ilmu, 2002.

Hamka. Tafsir Al-Az̧har. Jakarta: Gema Insani Press, 2015.

Katsir, Imaduddin Abi al-Fida Isma'il ibn. Tafsir Al-Qur'an al-Az̧bim. Kairo: Maktabah al-Shafa, 2004.

Liham, Muhammad Said al-. Al-Mu'jam al-Mufahras Li Alfaz̧h al-Qur'an. Beirut: Dar al-Ma'rifah, 2002.

Mahalli, Jalâl al-Dîn Muhammad Ibn Ahmad al-, and Jalâl al-Dîn 'Abdurrahman Ibn Abi Bakr al-Suyûthî. Tafsir Jalalain. Kairo: Dar al-Hadits, n.d.

Maraghi, Ahmad Ibn al-Musthafâ al-. Tafsir Al-Maraghi. Mesir: al-Bâb al-Halabî, 1946.

Mulkhan, Abdul Munir. Paradigma Intelektual Muslim, Pengantar Filsafat Pendidikan Islam Dan Dakwah. Yogyakarta: Pustaka Pelajar, 2003.

Nasution, Harun. Akal Dan Wahyu Dalam Islam. Jakarta: UI Press, 1996.

Qaththân, Manna al-. Mababits Fi 'Ulum al-Qur'An. Kairo: Maktabah Wahbah, 2000 .

Quthb, Sayyid. Fi Zhilal Al-Qur'an. Kairo: Dar al-Syuruq, 1998.

Rahmat, Jalaluddin. Islam Alternatif. Bandung: Mizan, 1999.

Shihab, M. Quraish. Tafsir Al-Misbab: Pesan, Kesan Dan Keserasian Al-Qur'an. Jakarta: Lentera Hati, 2002.

- Tafsir Al-Mishbab: Pesan, Kesan Dan Keserasian al-Qur'an,. Vol. 2. Jakarta: Lentera Hati, 2011.

Syari'ati, Ali. Tugas Cendekiawan Muslim. Jakarta: Rajawali Press, 1991. 